\title{
Review
}

Journal of Innate

Immunity
$\mathrm{J}$ Innate Immun 2011;3:577-584

DOI: $\underline{10.1159 / 000330668}$
Received: March 29, 2011

Accepted after revision: June 27, 2011

Published online: September 5, 2011

\section{Roryt+ Innate Lymphoid Cells in Intestinal Homeostasis and Immunity}

\author{
Patricia Aparicio-Domingo Tom Cupedo \\ Department of Hematology, Erasmus University Medical Center, Rotterdam, The Netherlands
}

\section{Key Words}

Cytokines $\cdot$ Host defense $\cdot$ Immune response $\cdot$

Toll-like receptor $\cdot$ Innate lymphoid cells $\cdot$ Ror $\gamma \mathrm{t}$

\begin{abstract}
Innate lymphoid cells (ILC) combine innate and adaptive immune functions and are part of the first line of defense against mucosal infections. ILC are set apart from adaptive lymphocytes by their independence on RAG genes and the resulting absence of specific antigen receptors. In this review, we will discuss the biology and function of intestinal ILC that express the nuclear hormone receptor Roryt (encoded by the Rorc gene) and highlight their role in intestinal homeostasis and immunity.

Copyright $\odot 2011$ S. Karger AG, Basel
\end{abstract}

\section{Ror $\mathbf{t +}$ Innate Lymphoid Cells}

Expression of Roryt delineates a heterogeneous group of ILC that depend on RORC and the helix-loop-helix protein ID2 for their development [1-7]. Roryt+ ILC have a variety of phenotypes that might represent either activation states or progressive developmental intermediates of one cell lineage, or distinct lineages of Roryt+ ILC that share a common precursor.

In the fetal murine intestine the predominant ILC population is characterized by expression of CD117 (ckit) and CD127 (IL7R $\alpha)[8,9]$. The majority of these Roryt+ ILC express CD4 and were previously termed lymphoid tissue inducer (LTi) cells because of their

\section{KARGER}

Fax +4161306 1234

E-Mail karger@karger.ch

www.karger.com (c) 2011 S. Karger AG, Basel

1662-811X/11/0036-0577\$38.00/0

Accessible online at:

www.karger.com/jin function in the development of lymph nodes and Peyer's patches [10]. After birth, additional Ror $\gamma t+$ ILC populations appear in the intestines including cells with low CD117 expression and a population of Roryt+ ILC that express the natural cytotoxicity receptor (NCR) NKp46 [9].

In adult humans and mice, a substantial population of mucosal Ror $\gamma \mathrm{t}+$ ILC is characterized by the expression of NCRs [9, 11-13]. Murine intestinal-derived Ror $\gamma t+$ ILC express NKp46, while human tonsil-derived Ror $\gamma \mathrm{t}+$ ILC express NKp44 (table 1) [14, 15]. These Ig-like transmembrane receptors belong to a family of activating receptors initially recognized for their expression on natural killer (NK) cells that include NKp30, NKp46 and NKp44 [16]. NKp46 is constitutively expressed by human and mouse NK cells. NKp30 and Nkp44 are not expressed by mouse NK cells, but in humans are constitutively expressed and activation-dependent NK cell receptors, respectively. In addition to NCR, human Ror $\gamma \mathrm{t}+$ ILC can express the NK marker CD56 (NCAM-1) [14, 15] and mouse Ror $\gamma t+$ ILC express low levels of NK1.1 [11-13]. Nevertheless, Ror $\gamma \mathrm{t}+$ ILC and classical NK cells are clearly distinct cell lineages. First, Ror $\gamma t+$ ILC lack expression of killing inhibitory receptors, do not have a cytotoxic machinery and fail to produce perforin or granzyme $\mathrm{B}$, all of which are essential functional properties of NK cells $[14,15,17]$. Second, different cytokines are needed for the differentiation of these two lineages; normal development of ILC requires signaling through the IL7-R whereas NK cells are IL-15R dependent [13, 18-20]. Finally, human Roryt+ ILCs from palatine tonsils can be cloned and expanded ex vivo without loss of function, as observed by the maintenance of 
Table 1. Activating molecules expressed on mouse and human ILC

\begin{tabular}{llll}
\hline & Mouse & Human & References \\
\hline NKp30 & - & + & {$[15]$} \\
NKp44 & - & + & {$[14]$} \\
NKp46 & + or - & + or - & {$[11,12,14]$} \\
IL-23R & + & + & {$[11,12,14]$} \\
IL-1R & + & + & {$[47]$} \\
TLR1 & ND & $+{ }^{1}$ & {$[21,46]$} \\
TLR2 & $+^{2}$ & $+^{2}$ & {$[21,46]$} \\
TLR4 & $+{ }^{1}$ & $-{ }^{1}$ & {$[21,46]$} \\
TLR5 & ND & $+{ }^{1}$ & {$[21,46]$} \\
TLR6 & ND & $+{ }^{1}$ & {$[21,46]$} \\
TLR7 & ND & $+{ }^{1}$ & {$[21,46]$} \\
TLR9 & $-{ }^{1}$ & $+^{1}$ & {$[21,46]$} \\
\hline
\end{tabular}

ND $=$ Not determined.

${ }^{1}$ Detection of transcripts. ${ }^{2}$ Functional response.

Roryt expression, and without conversion into conventional NK cells [17].

ILC display several features normally associated with activated cells of the adaptive immune system. Similar to activated T and B cells, ILC express surface lymphotoxin$\alpha 1 \beta 2$ (LT) and can secrete TNF- $\alpha$ and IL-2 [21, 22]. In addition, ILC produce cytokines normally secreted by specific $T$ helper cells. In both humans and mice, ILC can secrete IL-22 and IL-17a, reminiscent of T helper 17 cells $[11-15,21,23,24]$. The main difference between adaptive immune cells and ILC is that the latter do not have a specific antigen receptor, and as a consequence will be activated in a non-antigen-specific manner.

The production of effector molecules associated with adaptive immunity, but without the antigen restriction, endows ILC with the ability to respond much quicker than adaptive cells, but also to function in an environment in which activating signals for adaptive cells are lacking. A prime example of this is the developing mammalian embryo.

\section{Lymphoid Organogenesis in the Intestine: Homeostasis}

The best studied population of Ror $\gamma \mathrm{t}+$ ILC are the cells that are responsible for delivering the inductive signals for lymphoid organ formation in the human and mouse embryo and were therefore designated LTi cells $[4$,
$6,15]$. In the absence of LTi cells no lymph nodes, Peyer's patches or cryptopatches (CP) develop [3-6, 22]. Essential for the lymphoid tissue-inducing capacity of LTi cells is their expression of membrane-bound LT and the expression of LT $\beta R$ by stromal cells at sites of lymphoid organogenesis [25-27].

The lymphoid tissues of the intestines are collectively referred to as the gut associated lymphoid tissues (GALT) and can be divided into programmed tissues that form during development, such as the gut-draining lymph nodes and the Peyer's patches, and induced tissues that form after birth driven by external signals [28]. Here we will briefly discuss the formation and function of GALT in relation to Roryt+ ILC. For a recent extensive review of the cellular and molecular interactions during lymphoid organ development, see van de Pavert and Mebius [10].

\section{Programmed Lymphoid Tissues: Lymph Nodes}

In mice, at least 40 lymph nodes are present [29] and humans are estimated to have between 500 and 700 individual lymph nodes [30]. Development of these secondary lymphoid organs is induced by activation of the local mesenchyme by ligation of the LT $\beta R$ through membranebound LT expressed on Ror yt+ LTi cells [31]. This activation results in secretion of homeostatic chemokines and expression of adhesion molecules. As a consequence, additional (precursor) LTi cells are recruited to the developing lymph node anlage. Via paracrine interactions LTi cell precursors are allowed to differentiate into mature LTi cells, establishing a positive feedback loop resulting in the maturation of specific stromal cell subsets that in progressive developmental steps will control the influx of rearranging adaptive immune cells [31].

\section{Programmed Lymphoid Tissues: Peyer's Patches}

Peyer's patches are located on the antimesenteric side of the small intestine, directly underlying the intestinal epithelium. Inbred mouse strains have on average 6-10 Peyer's patches, although the exact number varies between strains. The human small intestine contains approximately 240 Peyer's patches, with an increasing density towards the terminal ileum [32]. Peyer's patches are characterized by the presence of more than one $\mathrm{B}$ cell follicle and distinct interfollicular $\mathrm{T}$ cell areas with high endothelial venules [33]. The intestinal epithelium overlying the Peyer's patch- 
es contain microfold (M) cells that actively transport particles from the intestinal lumen into the Peyer's patch [34].

In mice, Peyer's patch development starts at embryonic day (E) 15.5, when CD117+CD11c+ lymphoid tissue initiator (LTin) cells cluster at distinct sites on the antimesenteric wall of the fetal small intestine colocalizing with VCAM-1-expressing stromal cells $[35,36]$. In additional developmental steps, Ror $\gamma \mathrm{t}+\mathrm{LTi}$ cells are recruited to the developing Peyer's patches and the VCAM-1+ stroma will start to organize the anlage into distinct microdomains [35, 37]. In the absence of LTi cells, as is the case in mice with a targeted deletion of Rorc or id2, Peyer's patch development is terminated at E16.5.

\section{Programmed Lymphoid Tissues: Cryptopatches}

Since the intestinal immune system has to be able to respond to changes in the composition of the intestinal microbiota by mounting immune responses against pathogens while being in a homeostatic equilibrium with commensal bacteria [28], it has evolved a unique set of lymphoid tissues that function as a dynamic system with the ability to respond swiftly to changes in microbial pressure through the generation of IgA-producing plasma cells. The basis for this flexible immune compartment is formed by small lymphocyte clusters termed CP that contain mainly Roryt+ ILC and dendritic cells, but only very few $\mathrm{B}$ or $\mathrm{T}$ cells [8]. The murine small intestine contains approximately $1,500 \mathrm{CP}$ and the colon about 150 [8]. Similar to Peyer's patches, CP are in direct contact with $\mathrm{M}$ cell-containing epithelium. Similar to other programmed lymphoid tissues, development of CP depends on LT $\beta R$ signaling and Ror $\gamma t$-expressing ILC [38, 39]. Under the influence of microbial-derived signals, $\mathrm{CP}$ have the capacity to attract $\mathrm{B}$ cells and transform into an isolated lymphoid follicle (ILF) [40, 41].

\section{Inducible Lymphoid Tissues: Isolated Lymphoid Follicles}

ILF are histologically characterized by the presence of a single B cell follicle containing follicular dendritic cells and scattered $\mathrm{T}$ cells without a well-defined $\mathrm{T}$ cell area [40]. Similar to their CP ancestors, ILF remain in direct contact with $\mathrm{M}$ cell-containing intestinal epithelium. Upon activation, B cells within the ILF can enter germinal center reactions and differentiate into plasma and memory B cells [39]. Not surprisingly, the majority of plasma cells generated in ILF produce IgA, a protective immunoglobulin that can be actively transported across the epithelial barrier upon migration of plasma cells into the lamina propria.

The transition from CP into ILF depends on microbial derived signals, and in germ-free mice no ILF develop. In addition, Roryt+ ILC-mediated activation of stromal cells in the $\mathrm{CP}$ is essential for the regulated transition from CP to ILF, establishing Roryt+ ILC as master regulators of development of CP and differentiation of ILF, in line with their function during embryonic development of lymphoid tissues [38, 39].

As mentioned in the previous paragraph, ILF contain ill-defined $\mathrm{T}$ cell areas. This already suggests that ILF are lymphoid organs in which $\mathrm{T}$ cells are not essential for supporting $\mathrm{B}$ cell responses, a notion that is confirmed by the fact that ILF can generate IgA-producing plasma cells in the absence of T cells [39]. As such, a third function of Roryt+ ILC in CP-ILF development and function becomes apparent. Through their production of TNF- $\alpha$, Ror $\gamma \mathrm{t}+$ ILC can activate production of MMPs by stromal cells and macrophages within the ILF. These MMP can in turn activate latent TGF- $\beta$ which is an important switch factor for the generation of IgA [39].

\section{Lymphoid Organogenesis in the Intestine: Epithelial Damage}

Formation of inducible lymphoid tissues in the intestines is part of the normal development of the homeostatic equilibrium of intestinal immunity and the commensal microflora. However, there are many examples of lymphoid tissues forming in adulthood in response to chronic immune activation during infections, autoimmune diseases and some forms of cancer [42]. The exact function of these so-called tertiary lymphoid tissues is still unresolved and might be either beneficial or pathological depending on the disease, the tissue or even the stage of disease. Many of the effector molecules expressed by fetal Roryt+ ILC that are essential for induction of the programmed lymphoid tissues and even of the $\mathrm{CP}$ are also expressed by activated T cells, B cells or NK cells. This suggests that during inflammation, when tertiary lymphoid tissues can form, many different immune cells might have lymphoid tissue-inducing capacity.

The intestinal immune system keeps equilibrium with the commensal flora by means of a continuous state of activation that prevents bacterial dissemination yet allows for stable colonization. Despite this height- 
ened activation state, most organogenic events that occur in the intestines, such as the maturation of ILF, are controlled by Roryt+ ILC rather than by activated adaptive immune cells. However, during chronic inflammatory diseases like Crohn's disease or persistent infections like Helicobacter pylori in the stomach, lymphoid neogenesis occurs which is most likely independent of Roryt+ ILC [42]. In experimental systems, the lymphoid tissue-inducing capacity of activated B cells in the intestines was recently compellingly shown. Mice with a targeted deletion of rorc, which lack all Roryt+ ILC, Peyer's patches and $\mathrm{CP}$, harbor about 3 times more $\mathrm{B}$ cell aggregates in the noninflamed colon in comparison to wildtype mice [43]. These aggregates, which are mainly ILF and colonic patches, develop in mice in the absence of Roryt+ ILC and CP.

Anatomically, ILF induced in the absence of Ror $\gamma \mathrm{t}+$ ILC are histologically indistinguishable from those found in wild-type mice. Yet there is a clear shift in function. In spite of the increase in total numbers of ILF in the absence of Roryt, the number of IgA-producing plasma cells is strongly reduced [39]. Instead, IgG-producing cells are now found within the lamina propria [43]. This shift away from protective IgA and towards a more inflammation-related $\mathrm{B}$ cell response does not lead to overt intestinal inflammation or microbial dissemination during normal homeostatic conditions [43]. In contrast, upon intestinal damage this newly found balance is lost. While DSS administration increases the number of ILF in rorc-/- mice in a manner that is still comparable to wild-type mice, this inflammation-induced ILF formation in the absence of ILC is driven by LT-expressing activated B cells [43]. Upon DSS exposure, Ror $\gamma \mathrm{t}$-deficient mice succumb to a severe colitis, which is accompanied by wasting disease and excessive recruitment of neutrophils [43]. The shift in immunoglobulin production from IgA to IgG that was already present at homeostasis is amplified with the increase in ILF numbers in response to DSS. The exacerbated response seems linked to the aberrant production of IgG as administration of intravenous immunoglobulin could partially revert disease severity [43]. However, how immunoglobulins are mechanistically linked to the wasting disease and excessive recruitment of neutrophils remains to be unraveled.

These data implicate Roryt+ ILC in controlling the balance between IgA and IgG that is generated in ILF, ensuring that during homeostasis and especially during responses to epithelial damage, protective $\operatorname{IgA}$ is the dominant isotype produced in response to the commensal microbiota. In the absence of Roryt+ ILC, IgA-pro- ducing plasma cells are reduced concomitant with an increase in IgG-secreting plasma cells [39, 43]. In addition, the number of ILF increases in an LT $\beta R$-dependent, yet ILC-independent manner. One might therefore speculate that intestinal lymphoid tissues that are not under the control of Roryt+ ILC, including presumably those formed during chronic inflammatory responses, abide to different rules and are subject to alternative forms of regulation. If this regulation changes, and IgG plasma cells are formed, this can aggravate disease.

\section{Production of Th17-Associated Cytokines}

An additional level of complexity is brought upon by the fact that Roryt+ ILC also directly influence intestinal epithelial cells through production of cytokines that affect epithelial fitness and function $[13,14,24,44,45]$.

In both mice and humans, Roryt+ ILC have the capacity to produce the Th17 associated cytokines IL-17a and IL-22 [9, 11-15, 24]. Especially the latter is associated with Roryt+ ILC located in mucosal tissues [2]. In murine intestines, Ror $\gamma \mathrm{t}+$ ILC are the main cellular source of IL-22 [24]. IL-22 is essential in intestinal homeostasis and participates in host defense in a direct manner. Given the close proximity to external antigens, the intestinal epithelial cell layer requires a fine-tuned regulation to maintain and safeguard intestinal integrity. Ligation of the IL$22 \mathrm{R}$ present on epithelial cells regulates the expression of antimicrobial peptides which are secreted into the intestinal lumen and are important for maintaining the balance with the microbiota and preventing the attachment of bacteria to the epithelium $[13,14,24,44,45]$. As the main cellular source of IL-22 in the intestines, Ror $\gamma \mathrm{t}+$ ILC are located directly underneath the epithelium, both in the lamina propria as well as in CP, ideally positioned for regulating the intestinal epithelium.

So far, it remains to be determined what the physiological signals are that activate production of IL-22 in Roryt+ ILC. While in vitro, both mouse and human Roryt+ ILC respond to IL-23 with induction of IL-22 secretion (table 1) [11-14, 17], in vivo, murine intestinal Roryt+ ILC do not depend on IL-23 for their homeostatic production of IL-22 (fig. 1) [24].

In cultured human tonsil-derived Roryt+ ILC, IL-23 alone is not sufficient to induce IL-22 and requires an additional co-stimulatory signal. This second signal can be either a cytokine such as IL-2 or a TLR ligand [21]. Tonsilderived Roryt+ ILC also secrete IL-2, making them a unique non-T cell source of this cytokine [21]. However, 


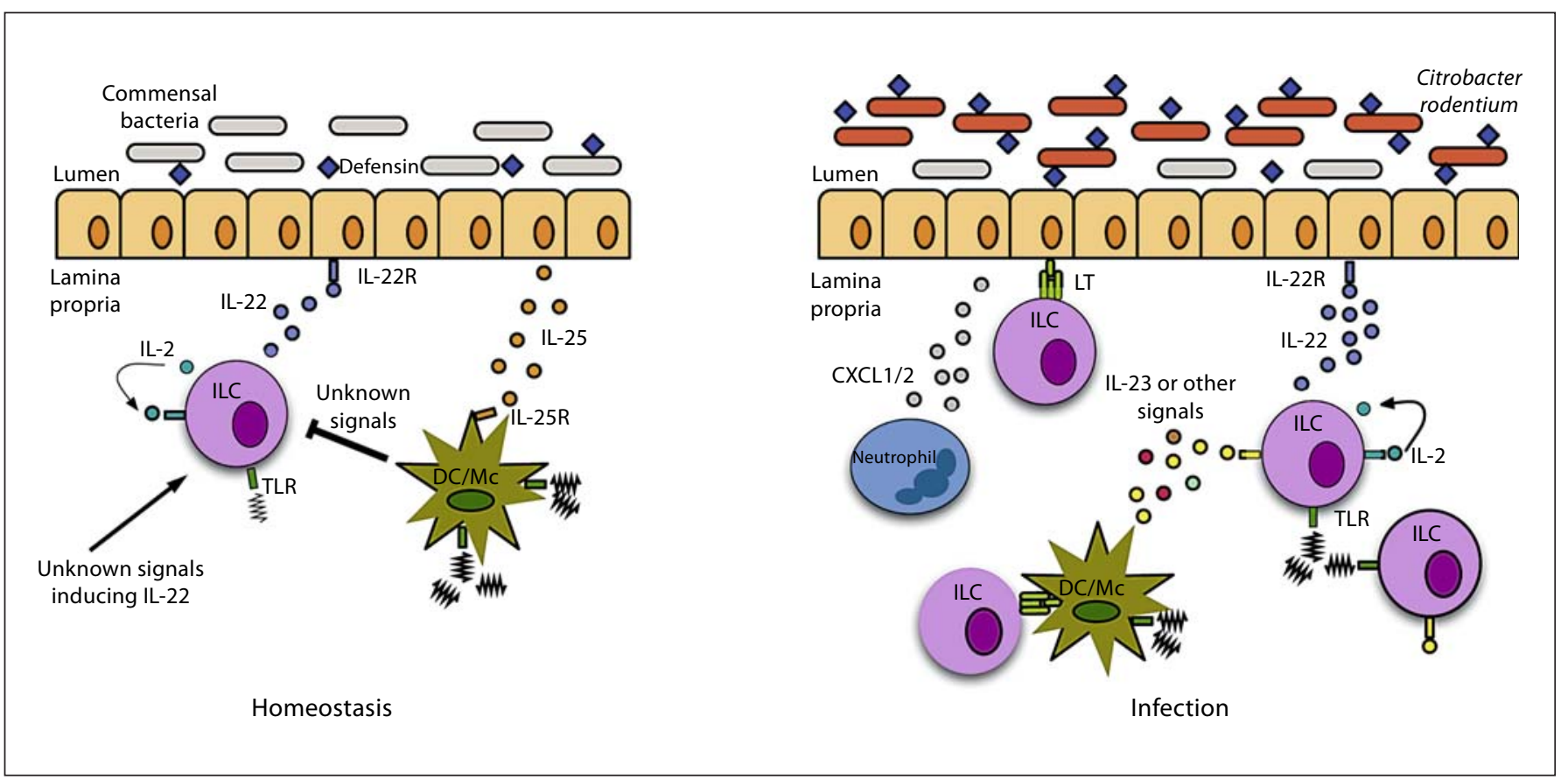

Fig. 1. Intestinal Roryt+ ILC in homeostasis and infection. During homeostasis (left panel), Roryt+ ILC produce IL-22 in an IL23 -independent manner. The epithelial cells in turn produce and secrete antimicrobial peptides such as defensin to restrict the local microbiota. The magnitude of ILC-derived IL-22 production is controlled by signals emanating from IL-25 stimulated dendritic cells or macrophages. IL-25 is produced by epithelial cells in response to the commensal flora. IL-22 is also controlled by autocrine IL-2 and by TLR ligation. During infection with C. rodentium (right panel), the inhibition of IL-22 levels via IL-25 is lifted and IL-22 production is increased via IL-23 and other unknown signals. In addition, ILC can ligate the LT $\beta$ R on epithelial cells as well as on dendritic cells or macrophages and induce neutrophil influx and control the infection. DC/Mc = Dendritic cell/ macrophage. the amount of IL-2 secreted in culture is not sufficient to act in an autocrine manner in conjunction with IL-23. Whether this could be different in vivo, when inflammatory signals might induce higher levels of IL-2, is an important unanswered question.

In addition, human and mouse Roryt+ ILC express TLRs (table 1) and in human ILC signaling through TLR2 can function as a co-stimulatory signal in conjunction with IL-23 or IL-15 [21]. In vivo, the TLR-2 ligand zymosan is able to induce IL-22 production in murine Ror $\gamma \mathrm{t}+$ ILC in an indirect manner, dependent on IL-23 [23]. A likely intermediate in this ILC activation are macrophages/dendritic cells that express TLRs and can produce IL-23. TLR2 and TLR4 ligation can also indirectly influence the levels of OX40L, CD30L and RANKL expressed on ILC [46].

Roryt+ ILC also have the ability to produce the proinflammatory Th-17 cytokine IL-17a. In humans, Ror $\gamma \mathrm{t}+$ ILC derived from fetal developing lymph nodes contain transcripts for $i l 17 a$, while lacking il22 transcripts [15]. The function of IL-17 in lymph node development is still unclear, as IL-17-deficient mice do not have obvious defects in lymphoid organogenesis. Roryt+ ILC in murine fetal intestines also produce IL-17a, in concert with IL-22 [24].

The only reported induction of IL-17a in cultured human Roryt+ ILC involved signaling through the IL-1R [47]. This suggests that specific inflammation-related signals might control the production of IL-17a in an antigen-independent manner. In vitro, induction of IL-17a occurred in cells that were also exposed to IL-7 and/or SCF, and it is conceivable that in parallel to the induction of IL-22 a combination of signals is needed for IL17 a secretion. Since IL-17a is a very potent pro-inflammatory cytokine, its expression in Thelper cells is under tight control and requires a strong TCR signal in conjunction with the right cytokine environment. Since Roryt+ ILC lack specific antigen receptors, control of IL-17a production will probably be regulated through a combination of specific signals to avoid untimely release of this cytokine. 


\section{Microbial Control of Ror $\gamma \mathbf{t +}$ ILC Activation}

There are contradictory data on the role of the microbiota in controlling activation and IL-22 production by Roryt+ ILC, especially the NKP46+ subset. Initial experiments had shown that in germ-free mice, Roryt+ LTi cells develop normal, as expected by the presence of lymph nodes in these mice but that the Roryt+ NKp46+ cells were severely reduced $[11,13]$. In accordance with this, also IL-22 production in the intestines was severely impaired.

Recent reports indicate the opposite, suggesting that Roryt+ ILC in the sterile fetal murine intestine contain transcripts for both IL-22 and IL-17a, yet that in the presence of microbiota the levels of both cytokines progressively decrease with age, resulting in the complete absence of IL-17a in adult mice [24]. Commensal microbiota-induced production of IL-25 was shown to be responsible for the decrease in IL-22 secretion by adult murine intestinal Ror $\gamma \mathrm{t}+$ ILC and in germ-free mice IL22 production by Ror $\gamma t+$ ILC was increased [24].

At present it is very difficult to reconcile these different viewpoints. There is clearly an important role for the microbiota in regulating basal function of intestinal Roryt+ LTi cells. This mere fact might already reveal part of the underlying problem, as microbial content is likely to differ in the various animal facilities. This would, however, not explain the opposite findings with germ-free mice.

Of note, IL-23 is not essential for the production of IL22 by Ror $\gamma \mathrm{t}+$ ILC in the intestines, indicating that other mechanisms of regulation are at play [24]. The microbiota and Roryt+ ILC thus maintain a fine balance tuned to optimized homeostasis. When this balance is disrupted by experimentally induced epithelial damage, IL-22 production by Roryt+ ILC increases and aids in the restoration of the intestinal barrier through direct effects on epithelial cells [43].

\section{Enteric Infections: IL-22}

During homeostasis or at times of epithelial damage in the absence of pathogenic bacteria, IL-22 is produced by CD4+NKp46- ILC and by CD4-NKp46+ ILC. This is different at times of enteric infections with pathogenic bacteria.

A commonly used enterogenic bacterium is Citrobacter rodentium, a murine-specific enteric pathogen that causes acute colitis, resembling human enteropathogenic and entherohemorrhagic Escherichia coli. Studies with $C$. rodentium have shown the importance of Roryt+ ILCderived IL-22 in mediating early anti bacterial defenses and in avoiding bacterial dissemination [13, 44, 47]. IL$22 \mathrm{R}$ signaling on epithelial cells contributes to epithelial integrity and causes upregulation of genes encoding the antimicrobial peptide RegIII $\beta$, RegIII $\gamma$ and S100a [48].

IL-22-producing Roryt+ ILC show a steady increase in numbers during the immediate response to $C$. rodentium infection [44]. The importance of these cells in immunity against this bacterium is shown by the fact that infected Rag2-/- IL2ry-/- mice, which have less Roryt+ ILC and produce much lower levels of IL-22 as compared to Rag2-/- and Rag2-/- IL2r $\beta-/-$ mice resulting in failure to clear the pathogen and increased mortality $[13,44,49]$.

In contrast to the IL-22 response elicited by epithelial damage in the absence of pathogens, only the CD4+NKp46- ILC subset and not the NKp46+ ILC subset is essential for C. rodentium clearance [44]. Moreover, in the presence of pathogens, IL23R signaling in CD4+ Roryt+ ILC becomes an essential prerequisite for IL-22 secretion and bacterial clearance [44].

The importance of IL-22 in immunity to C. rodentium is further underscored by the fact that IL-22-deficient mice fail to recover from $C$. rodentium inoculation and succumb to the infection in the second week [44]. More precisely, experiments using neutralizing antibodies against IL-22 show that this cytokine is essential at the early stages of infection $[44,48]$. When IL-22 is neutralized at the time of infection, mice fail to clear the bacterium and die. In contrast, neutralizing IL-22 at later time points is progressively less deteriorating with $40 \%$ of the animal surviving IL-22 neutralization at day 4 . After 4 days, IL-22 is no longer necessary as neutralization after this point does not affect bacterial clearance or survival of the mice [44].

\section{Enteric Infections: IL-17a and IFN- $\gamma$}

A second experimental model of enteric inflammation in which Roryt+ ILC are implicated is the colitis induced by Helicobacter hepaticus in rag-deficient mice. In these mice, in the absence of adaptive immunity, $H$. hepaticus induces the production IL-17a and IFN- $\gamma$ by Ror $\gamma \mathrm{t}+$ ILC in an IL-23-dependent manner [50]. The pathogenic Roryt+ ILC in this model share several phenotypic characteristics with classical Ror $y \mathrm{t}+$ LTi cells except for the absence of CD117 (c-kit). These CD117low Roryt+ ILC accumulate in the inflamed colon and are directly responsible for the chronic pathology [50]. In an independent 
study, the developmental relationship of IL-22-producing ILC to IFN- $\gamma$-producing ILC was addressed. Ror $\gamma \mathrm{t}+$ ILC expressing NKp46 can downregulate Ror $\gamma \mathrm{t}$ and NKp46 [20]. This is accompanied by a loss of IL-22 production and the gain of IFN- $\gamma$ secretion. This conversion from a cell type actively involved in intestinal homeostasis to a more inflammation prone cell is driven by a loss of IL-7R signaling, which in the intestine can be the result of lower epithelial-derived IL-7 levels due to changed or decreased microbial pressure from the commensal microbiota [20]. Indeed, in germ-free mice this conversion occurred much more frequently. Again, this highlights the importance of the homeostatic equilibrium encompassing Roryt+ ILC, epithelial cells, lymphoid tissues and the commensal microbiota as well as the fact that disruption of this balance can result in pathology driven by a variety of mechanisms.

\section{Enteric Infections: Lymphotoxin}

Besides IL-22R signaling, the LT $\beta$ R pathway is also important for the clearance of $C$. rodentium [45]. Ligation of this receptor on intestinal epithelial cells induces the production of the chemokines CXCL1 and CXCL2, resulting in the recruitment of neutrophils to the site of the infection. Inhibiting LT $\beta R$ signaling provokes colonic pathology and early death in mice upon C. rodentium infection [45].

Again Roryt+ ILC are important in these models, being the cellular source of membrane LT $\alpha 1 \beta 2$ (LT), the ligand for LT $\beta R$. Mice that specifically lack LT in Roryt+ ILC show bacterial dissemination, disruption of the epi- thelial layer and high morbidity after $C$. rodentium infection [45]. Importantly, there is also a role for LT $\beta R$-expressing hematopoietic cells as transfer of bone marrowderived cells from LT $\beta$ R-/- to wild-type mice leads to susceptibility to infection and mortality in $60 \%$ of the mice. In addition, in mice that specifically lack LT $\beta R$ in intestinal epithelium LT $\beta$ R expression on hematopoietic cells can again partially protect against $C$. rodentium [45]. This manifests the relevance of LT $\beta R$ signaling in both epithelial cells and hematopoietic-derived cells to orchestrate an efficient response against $C$. rodentium infection (fig. 1) [45].

\section{Concluding Remarks}

Over the last few years, a pictures has unfolded of Roryt+ ILC as important regulators of intestinal homeostasis and the early defense against enterogenic pathogens, through a continuous crosstalk involving TLR ligands, epithelial cells and dendritic cells. The current challenges lie in reconciling the opposing results with regard to microbial influence on Roryt+ ILC as well as in translating our knowledge on murine ILC to human intestinal diseases in which Roryt+ ILC might have a role.

\section{Acknowledgements}

This work was supported by grants from the Netherlands Organization for Scientific Research (Zon-MW Vidi grant No. 91710377 to T.C.) and the Human Frontier Science Program (RGP0006/2009 to T.C.).

\section{References}

1 Spits H, Di Santo JP: The expanding family of innate lymphoid cells: regulators and effectors of immunity and tissue remodeling. Nat Immunol 2011;12:21-27.

$\checkmark 2$ Vivier E, Spits H, Cupedo T: Interleukin-22producing innate immune cells: new players in mucosal immunity and tissue repair? Nat Rev Immunol 2009;9:229-234.

-3 Kurebayashi S, Ueda E, Sakaue M, Patel DD, Medvedev A, Zhang F, Jetten AM: Retinoidrelated orphan receptor gamma (Ror $\gamma$ ) is essential for lymphoid organogenesis and controls apoptosis during thymopoiesis. PNAS 2000;97:10132-10137.

-4 Sun Z, Unutmaz D, Zou YR, Sunshine MJ, Pierani A, Brenner-Morton S, Mebius RE, Littman DR: Requirement for Ror $\gamma$ in thymocyte survival and lymphoid organ development. Science 2000;288:2369-2373.
5 Eberl G, Marmon S, Sunshine MJ, Rennert PD, Choi Y, Littman DR: An essential function for the nuclear receptor Roryt in the generation of fetal lymphoid tissue inducer cells. Nat Immunol 2004;5:64-73.

-6 Yokota Y, Mansouri A, Mori S, Sugawara S, Adachi S, Nishikawa S-I, Gruss P: Development of peripheral lymphoid organs and natural killer cells depends on the helix-loop-helix inhibitor Id2. Nature 1999;397:702-706.

-7 Boos MD, Yokota Y, Eberl G, Kee BL: Mature natural killer cell and lymphoid tissue-inducing cell development requires Id2-mediated suppression of e protein activity. J Exp Med 2007;204:1119-1130.
8 Kanamori Y, Ishimaru K, Nanno M, Maki K, Ikuta K, Nariuchi H, Ishikawa H: Identification of novel lymphoid tissues in murine intestinal mucosa where clusters of c-kit+ IL$7 \mathrm{r}+$ Thyl+ lympho-hemopoietic progenitors develop. J Exp Med 1996;184:1449-1459.

-9 Sawa S, Cherrier M, Lochner M, SatohTakayama N, Fehling HJ, Langa F, Di Santo JP, Eberl G: Lineage relationship analysis of Roryt+ innate lymphoid cells. Science 2010; 330:665-669.

10 van de Pavert SA, Mebius RE: New insights into the development of lymphoid tissues. Nat Rev Immunol 2010;10:664-674.

11 Sanos SL, Bui VL, Mortha A, Oberle K, Heners C, Johner C, Diefenbach A: Ror[gamma] $t$ and commensal microflora are required for the differentiation of mucosal interleukin 22 -producing NKp46+ cells. Nat Immunol 2009;10:83-91. 
-12 Luci C, Reynders A, Ivanov II, Cognet C, Chiche L, Chasson L, Hardwigsen J, Anguiano E, Banchereau J, Chaussabel D, Dalod M, Littman DR, Vivier E, Tomasello E: Influence of the transcription factor Roryt on the development of NKp46+ cell populations in gut and skin. Nat Immunol 2009;10:75-82.

$\checkmark 13$ Satoh-Takayama N, Vosshenrich CA, Lesjean-Pottier S, Sawa S, Lochner M, Rattis F, Mention JJ, Thiam K, Cerf-Bensussan N, Mandelboim O, Eberl G, Di Santo JP: Microbial flora drives interleukin 22 production in intestinal NKp46+ cells that provide innate mucosal immune defense. Immunity 2008; 29:958-970.

$\checkmark 14$ Cella M, Fuchs A, Vermi W, Facchetti F, Otero K, Lennerz JK, Doherty JM, Mills JC, Colonna M: A human natural killer cell subset provides an innate source of il-22 for mucosal immunity. Nature 2008;457:722-725.

15 Cupedo T, Crellin NK, Papazian N, Rombouts EJ, Weijer K, Grogan JL, Fibbe WE, Cornelissen JJ, Spits H: Human fetal lymphoid tissue-inducer cells are interleukin 17-producing precursors to $\mathrm{RORC}+\mathrm{CD} 127+$ natural killer-like cells. Nat Immunol 2009; 10:66-74.

- 16 Moretta A, Bottino C, Vitale M, Pende D, Cantoni C, Mingari MC, Biassoni R, Moretta L: Activating receptors and coreceptors involved in human natural killer cell-mediated cytolysis. Annu Rev Immunol 2001;19:197223.

17 Crellin NK, Trifari S, Kaplan CD, Cupedo T, Spits H: Human NKp44+IL-22+ cells and LTi-like cells constitute a stable RORC+ lineage distinct from conventional natural killer cells. J Exp Med 2010;207:281-290.

-18 Kim MY, Anderson G, White A, Jenkinson E, Arlt W, Martensson IL, Erlandsson L, Lane PJ: OX40 ligand and CD30 ligand are expressed on adult but not neonatal CD4+CD3- inducer cells: evidence that IL-7 signals regulate CD30 ligand but not OX40 ligand expression. J Immunol 2005; 174: 6686-6691.

-19 Satoh-Takayama N, Lesjean-Pottier S, Vieira P, Sawa S, Eberl G, Vosshenrich CA, Di Santo JP: IL-7 and IL-15 independently program the differentiation of intestinal CD3NKp46+ cell subsets from Id2-dependent precursors. J Exp Med 2010;207:273-280.

20 Vonarbourg C, Mortha A, Bui VL, Hernandez PP, Kiss EA, Hoyler T, Flach M, Bengsch B, Thimme R, Holscher C, Honig M, Pannicke U, Schwarz K, Ware CF, Finke D, Diefenbach A: Regulated expression of nuclear receptor Roryt confers distinct functional fates to NK cell receptor-expressing Ror $\mathrm{t}(+)$ innate lymphocytes. Immunity 2010;33:736-751.

-21 Crellin NK, Trifari S, Kaplan CD, SatohTakayama N, Di Santo JP, Spits H: Regulation of cytokine secretion in human CD127(+) lti-like innate lymphoid cells by toll-like receptor 2. Immunity 2010;33:752764.

-22 Mebius RE, Rennert P, Weissman IL: Developing lymph nodes collect CD4+CD3-LT $\beta+$ cells that can differentiate to APC, NK cells, and follicular cells but not T or B cells. Immunity 1997;7:493-504.

23 Takatori H, Kanno Y, Watford WT, Tato CM Weiss G, Ivanov, II, Littman DR, O'Shea JJ: Lymphoid tissue inducer-like cells are an innate source of IL-17 and IL-22. J Exp Med 2009;206:35-41.

24 Sawa S, Lochner M, Satoh-Takayama N, Dulauroy S, Berard M, Kleinschek M, Cua D, Di Santo JP, Eberl G: Roryt(+) innate lymphoid cells regulate intestinal homeostasis by integrating negative signals from the symbiotic microbiota. Nat Immunol 2011;12:320-326.

25 Rennert PD, Browning JL, Mebius R, Mackay F, Hochman PS: Surface lymphotoxin $\alpha / \beta$ complex is required for the development of peripheral lymphoid organs. J Exp Med 1996;184:1999-2006.

-26 Futterer A, Mink K, Luz A, Kosco-Vilbois $\mathrm{MH}, \mathrm{Pfeffer} \mathrm{K}$ : The lymphotoxin $\beta$ receptor controls organogenesis and affinity maturation in peripheral lymphoid tissues. Immunity 1998;9:59-70.

-27 Rennert PD, James D, Mackay F, Browning JL, Hochman PS: Lymph node genesis is induced by signaling through the lymphotoxin $\beta$ receptor. Immunity 1998;9:71-79.

28 Eberl G, Lochner M: The development of intestinal lymphoid tissues at the interface of self and microbiota. Mucosal Immunol 2009;2:478-485.

-29 Van den Broeck W, Derore A, Simoens P: Anatomy and nomenclature of murine lymph nodes: descriptive study and nomenclatory standardization in balb/canncrl mice. J Immunol Methods 2006;312:12-19.

30 Pabst R: Plasticity and heterogeneity of lymphoid organs. What are the criteria to call a lymphoid organ primary, secondary or tertiary? Immunol Lett 2007;112:1-8.

31 Mebius RE: Organogenesis of lymphoid tissues. Nat Rev Immunol 2003;3:292-303.

32 Cornes JS: Number, size, and distribution of Peyer's patches in the human small intestine: Part I. The development of Peyer's patches. Gut 1965;6:225-229.

33 Brandtzaeg P, Kiyono H, Pabst R, Russell MW: Terminology: nomenclature of mucosa-associated lymphoid tissue. Mucosal Immunol 2008;1:31-37.

34 Neutra MR, Frey A, Kraehenbuhl JP: Epithelial M cells: gateways for mucosal infection and immunization. Cell 1996;86:345-348.

- 35 Veiga-Fernandes H, Coles MC, Foster KE, Patel A, Williams A, Natarajan D, Barlow A, Pachnis V, Kioussis D: Tyrosine kinase receptor ret is a key regulator of Peyer's patch organogenesis. Nature 2007;446:547-551.

- 36 Adachi S, Yoshida H, Kataoka H, Nishikawa S: Three distinctive steps in Peyer's patch formation of murine embryo. Int Immunol 1997;9:507-514.

37 Hashi H, Yoshida H, Honda K, Fraser S, Kubo H, Awane M, Takabayashi A, Nakano H, Yamaoka Y, Nishikawa SI: Compartmentalization of Peyer's patch anlagen before lymphocyte entry. J Immunol 2001;166: 3702-3709.
8 Eberl G, Littman DR: Thymic origin of intestinal $\alpha \beta$ T cells revealed by fate mapping of Ror $\gamma t+$ cells. Science 2004;305:248-251.

39 Tsuji M, Suzuki K, Kitamura H, Maruya M, Kinoshita K, Ivanov II, Itoh K, Littman DR, Fagarasan S: Requirement for lymphoid tissue-inducer cells in isolated follicle formation and $\mathrm{T}$ cell-independent immunoglobulin a generation in the gut. Immunity 2008 ; 29:261-271.

40 Hamada H, Hiroi T, Nishiyama Y, Takahashi $\mathrm{H}$, Masunaga Y, Hachimura S, Kaminogawa $\mathrm{S}$, Takahashi-Iwanaga H, Iwanaga T, Kiyono $\mathrm{H}$, Yamamoto H, Ishikawa H: Identification of multiple isolated lymphoid follicles on the antimesenteric wall of the mouse small intestine. J Immunol 2002;168:57-64.

- 41 Bouskra D, Brezillon C, Berard M, Werts C, Varona R, Boneca IG, Eberl G: Lymphoid tissue genesis induced by commensals through Nod1 regulates intestinal homeostasis. Nature 2008;456:507-510.

42 Aloisi F, Pujol-Borrell R: Lymphoid neogenesis in chronic inflammatory diseases. Nat Rev Immunol 2006;6:205-217.

43 Lochner M, Ohnmacht C, Presley L, Bruhns P, Si-Tahar M, Sawa S, Eberl G: Microbiotainduced tertiary lymphoid tissues aggravate inflammatory disease in the absence of Rory T and LTi cells. J Exp Med 2011;208:125-134.

-44 Sonnenberg GF, Monticelli LA, Elloso MM, Fouser LA, Artis D: CD4(+) lymphoid tissueinducer cells promote innate immunity in the gut. Immunity 2010;34:122-134.

45 Wang Y, Koroleva EP, Kruglov AA, Kuprash DV, Nedospasov SA, Fu YX, Tumanov AV: Lymphotoxin $\beta$ receptor signaling in intestinal epithelial cells orchestrates innate immune responses against mucosal bacterial infection. Immunity 2010;32:403-413.

46 Han S, Koo J, Bae J, Kim S, Baik S, Kim MY: Modulation of TNFSF expression in lymphoid tissue inducer cells by dendritic cells activated with Toll-like receptor ligands. BMB Rep 2011;44:129-134.

47 Cella M, Otero K, Colonna M: Expansion of human NK-22 cells with IL-7, IL-2, and IL-1 $\beta$ reveals intrinsic functional plasticity. Proc Natl Acad Sci USA 2010;107:10961-10966.

48 Zheng Y, Valdez PA, Danilenko DM, Hu Y, Sa SM, Gong Q, Abbas AR, Modrusan Z, Ghilardi N, de Sauvage FJ, Ouyang W: Interleukin-22 mediates early host defense against attaching and effacing bacterial pathogens. Nat Med 2008;14:282-289.

- 49 Satoh-Takayama N, Dumoutier L, LesjeanPottier S, Ribeiro VS, Mandelboim O, Renauld JC, Vosshenrich CA, Di Santo JP: The natural cytotoxicity receptor NKp46 is dispensable for IL-22-mediated innate intestinal immune defense against citrobacter rodentium. J Immunol 2009;183:6579-6587.

50 Buonocore S, Ahern PP, Uhlig HH, Ivanov, II, Littman DR, Maloy KJ, Powrie F: Innate lymphoid cells drive interleukin-23-dependent innate intestinal pathology. Nature 2010;464:1371-1375. 